\title{
Photoaquation of Carbonylpentacyanoferrate(II)
}

\author{
Arnd Vogler and Horst Kunkely \\ Institut für Chemie, Universität Regensburg \\ (Z. Naturforsch. 30 b, 355-357 [1975]; eingegangen am 18. März 1975) \\ Cyanoferrate(II) Complexes, Absorption Spectra, Photochemistry
}

\begin{abstract}
Upon ligand field excitation (300 nm-370 nm irradiating wavelengths) aqueous $\mathrm{Fe}(\mathrm{CN})_{5} \mathrm{CO}^{3-}$ underwent a photosubstitution under release of $\mathrm{CO}$ and formation of $\mathrm{Fe}(\mathrm{CN})_{5} \mathrm{H}_{2} \mathrm{O}^{3-}$ with the quantum yield 0.9 .
\end{abstract}

\section{Introduction}

The photochemistry of aqueous $\mathrm{Fe}(\mathrm{CN})_{6}{ }^{4-}$ and some of its monosubstituted complexes has been extensively investigated ${ }^{1}$. Most of this work was done with $\mathrm{Fe}(\mathrm{CN})_{6}{ }^{4-}$. It is generally recognized that this complex photoaquates under formation of $\mathrm{Fe}(\mathrm{CN})_{5} \mathrm{H}_{2} \mathrm{O}^{3-}$ when the irradiated absorption band is of the ligand field type. However, the primary photochemical step is apparently followed by secondary photochemical and fast thermal reactions which are not fully understood. Even an unambigous identification and characterization of $\mathrm{Fe}(\mathrm{CN})_{5} \mathrm{H}_{2} \mathrm{O}^{3-}$ was not yet achieved. The electronic absorption spectra of $\mathrm{Fe}(\mathrm{CN})_{5} \mathrm{H}_{2} \mathrm{O}^{3-}$ which have been reported ${ }^{2-6}$ disagree with regard to the number, wavelength, and intensity of the absorption maxima. The origin of this confusion does not seem to be clear. It has been suggested that $\mathrm{Fe}(\mathrm{CN})_{5} \mathrm{H}_{2} \mathrm{O}^{3-}$ is very unstable ${ }^{1}$. Some evidence was obtained that $\mathrm{Fe}(\mathrm{CN})_{5} \mathrm{H}_{2} \mathrm{O}^{3-}$ may exist in equilibrium with $\mathrm{Fe}(\mathrm{CN})_{5} \mathrm{OH}^{4-}$ dependent on the $\mathrm{pH}$ of the solution ${ }^{6}$. A further and possibly very important complication may be due to the formation of binuclear complexes as $\mathrm{Fe}_{2}(\mathrm{CN})_{11}{ }^{7-}$ or $\mathrm{Fe}_{2}(\mathrm{CN})_{10}{ }^{6-4,6, ?}$.

The light sensitivity of $\mathrm{Fe}(\mathrm{CN})_{5} \mathrm{CO}^{3-}$ was first observed in $1899^{8}$. Although the photochemistry of this complex has not yet been investigated in detail it is known that upon exposure to sun light an aqueous solution of $\mathrm{Fe}(\mathrm{CN})_{5} \mathrm{CO}^{3-}$ readily evolves carbon monoxide ${ }^{9,10}$. Surprisingly, in 1961 it was reported that this complex is resistant to sun light ${ }^{11}$. If release of $\mathrm{CO}$ takes place as the only photo-

Requests for reprints should be sent to Prof. Dr. A. VoGLER, Institut für Chemie, Universität Regensburg, D-8400 Regensburg, Postfach. chemical reaction of aqueous $\mathrm{Fe}(\mathrm{CN})_{5} \mathrm{CO}^{3-}$ some complications, which are encountered in the photolysis of $\mathrm{Fe}(\mathrm{CN})_{6}{ }^{4-}$, may be eliminated. Since the released $\mathrm{CO}$ can escape from the solution a thermal regeneration of the starting complex may not be important. In addition, a change of the $\mathrm{pH}$ should not accompany the photolysis of the carbonyl complex if $\mathrm{Fe}(\mathrm{CN})_{5} \mathrm{H}_{2} \mathrm{O}^{3-}$ is the only product.

\section{Material}

\section{Experimental}

$\mathrm{Na}_{3}\left[\mathrm{Fe}(\mathrm{CN})_{5} \mathrm{CO}\right] \cdot \mathrm{H}_{2} \mathrm{O}$. A suspension of $6.52 \mathrm{~g}$ $\mathrm{Na}_{3}\left[\mathrm{Fe}(\mathrm{CN})_{5} \mathrm{NH}_{3}\right] \cdot 3 \mathrm{H}_{2} \mathrm{O}^{9}$ in $200 \mathrm{ml}$ dimethylsulfoxide ist heated to $160^{\circ} \mathrm{C}$. Simultaneously a vigorous $\mathrm{CO}$ stream is bubbled through the suspension. After two hours the suspension is cooled down to $100^{\circ} \mathrm{C}$. Upon filtration of the hot suspension a slightly yellow solution is obtained. Upon addition of acetone the solution is cooled for one hour at $-20^{\circ} \mathrm{C}$. A colorless powder precipitates. It is collected by filtration and washed with acetone and ether. A purification is achieved by dissolving the product in hot ethanol $(80 \%)$ and reprecipitating with acetone. The colorless solid is dried at $120^{\circ} \mathrm{C}$ under vacuum.

$$
\begin{array}{cccc}
\text { Anal. for } & \mathrm{Na}_{3}\left[\mathrm{Fe}(\mathrm{CN})_{5} \mathrm{CO}\right] \cdot \mathrm{H}_{2} \mathrm{O} \\
\text { Calcd } & \mathrm{C} 23.90 & \mathrm{~N} 23.30 & \mathrm{H} 0.66, \\
\text { Found } & \mathrm{C} 23.85 & \mathrm{~N} 23.36 & \mathrm{H} 0.5 .
\end{array}
$$

\section{Photolysis procedure and analysis}

The light source used was a $100 \mathrm{~W}$ Osram highpressure mercury lamp. The filter combination Schott UG 11 and Schott WG 320 transmitted light between $300 \mathrm{~nm}$ and $370 \mathrm{~nm}$. An interference filter Schott 313 limited the ultraviolet radiation emitted to the wavelength of the mercury line at $313 \mathrm{~nm}$. A reflection filter Schott 250 transmitted light around $250 \mathrm{~nm}$ including the mercury line at $254 \mathrm{~nm}$.

The photolyses were carried out in 5-cm cylindrical spectrophotometer cells using neutral solu- 
tions of the complex at room temperature. A 10-cm cell was used to observe the spectral variations at very low concentrations of the complex $\left(\sim 10^{-5} \mathrm{M}\right)$. For quantum-yield determinations the concentrations were adjusted to optical densities greater than 2 within the region of the irradiating wavelengths to have essentially complete light absorption by the complex (about $2 \times 10^{-3} \mathrm{M}$ for irradiations in the region between 300 and $370 \mathrm{~nm}$ ). The total amount of photolysis was limited to less than 5\%. Absorbed light intensities were determined by ferrioxalate actinometry $^{12}$. Carbon monoxide determinations of photolyzed solutions and those kept in the dark were carried out according to a published procedure $^{13}$.

\section{Measurements}

Visible and ultraviolet spectra were measured with a Cary 14 recording spectrophotometer and a Zeiss PMQ II spectrophotometer for measurements at selected wavelengths.

\section{Results}

The preparation of $\mathrm{Na}_{3}\left[\mathrm{Fe}(\mathrm{CN})_{5} \mathrm{CO}\right] \cdot \mathrm{H}_{2} \mathrm{O}$ was achieved by the modification of a literature procedure ${ }^{9}$. The complex was obtained as a colorless solid. The absorption spectrum of aqueous $\mathrm{Fe}(\mathrm{CN})_{5} \mathrm{CO}^{3-}$ is given in Fig. 1. The exposure to

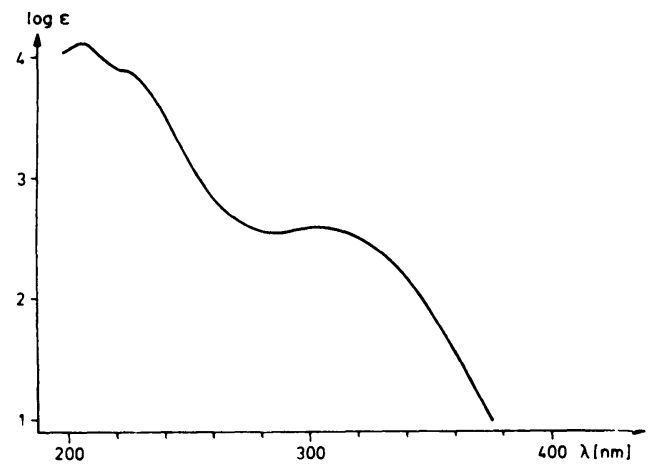

Fig. 1. Electronic absorption spectrum of $\mathrm{Fe}(\mathrm{CN})_{5} \mathrm{CO}^{3-}$.

visible light does not cause any chemical change. This observation is not surprising since the complex does not absorb above $380 \mathrm{~nm}$. However, the aqueous solution is very sensitive to UV light. Irradiation of the low-energy band $(300 \mathrm{~nm}-370$ $\mathrm{nm}$ irradiating wavelengths) caused immediate evolution of CO. Free cyanide was not detected. The $\mathrm{pH}$ remained constant. The irradiation was accompanied by a change of the absorption spectrum (Fig. 2). Two clear isosbestic points appeared.

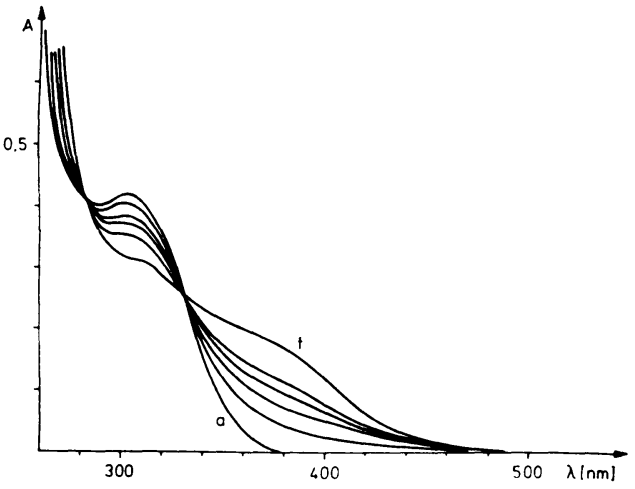

Fig. 2. Spectral changes during the photolysis of $1.1 \times$ $10^{-3} \mathrm{M} \mathrm{Fe}(\mathrm{CN})_{5} \mathrm{CO}^{3-}$ in water, $1-\mathrm{cm}$ cell, $300 \mathrm{~nm}-$ $370 \mathrm{~nm}$ irradiating wavelengths; irradiation time: $0 \min (a), 1 \min , 2 \min , 3 \mathrm{~min}, 4 \mathrm{~min}, 8 \min$ (f).

The pattern of these spectral variations did not change upon dilution down to $10^{-5} \mathrm{M} \mathrm{Fe}(\mathrm{CN})_{5} \mathrm{CO}^{3-}$. If light absorption by the starting complex was complete the reaction followed a zeroth order kinetics. However, after prolonged photolysis the isosbestic points disappeared indicating an interference by secondary photolysis or thermal reactions of the primary photoproduct. The concentration of released $\mathrm{CO}$ was determined according to a published procedure ${ }^{13}$. Upon irradiation with light between $300 \mathrm{~nm}$ and $370 \mathrm{~nm}$ the quantum yield was $0.90 \pm 0.05$. At $313 \mathrm{~nm}$ irradiating wavelength the quantum yield of $\mathrm{CO}$ evolution was found to be $0.86 \pm 0.05$.

These results suggest strongly that the photolysis of $\mathrm{Fe}(\mathrm{CN})_{5} \mathrm{CO}^{3-}$ led to the release of $\mathrm{CO}$ under formation of $\mathrm{Fe}(\mathrm{CN})_{5} \mathrm{H}_{2} \mathrm{O}^{3-}$ as the only primary photoproduct. The formation of $\mathrm{Fe}(\mathrm{CN})_{5} \mathrm{OH}^{4-}$ can be excluded since the photolysis was not accompanied by a change of the $\mathrm{pH}$. It seems unlikely that under our experimental conditions binuclear complexes may have been formed because the spectral variations were independent of the concentration of $\mathrm{Fe}(\mathrm{CN})_{5} \mathrm{CO}^{3-}$ down to $10^{-5} \mathrm{M}$ solutions. From the change of the absorption spectrum, which occured upon irradiation, and an independent analysis of released $\mathrm{CO}$ the spectrum of $\mathrm{Fe}(\mathrm{CN})_{5} \mathrm{H}_{2} \mathrm{O}^{3-}$ was calculated. Above $300 \mathrm{~nm}$ this complex exhibits only one absorption maximum at $392 \mathrm{~nm}$ $(\varepsilon=290)$.

\section{Discussion}

The electronic absorption spectrum of $\mathrm{Fe}\left(\mathrm{CN}_{5}\right) \mathrm{CO}^{3-}$ (Fig. 1) resembles closely that of $\mathrm{Fe}(\mathrm{CN})_{0}^{4-14}$. This 
observation is not surprising since $\mathrm{CN}^{-}$and $\mathrm{CO}$ are good $\pi$-acceptors and high in the spectrochemical series. The long-wavelength absorption maximum of $\mathrm{Fe}(\mathrm{CN})_{6}{ }^{4-}$ at $322 \mathrm{~nm}(\varepsilon=302)$ has been assigned to the lowest spin-allowed $\mathrm{LF}$ transition ${ }^{1} \mathrm{~A}_{1 \mathrm{~g}} \rightarrow{ }^{1} \mathrm{~T}_{1 \mathrm{~g}}$ in $\mathrm{O}_{\mathrm{h}}$ symmetry ${ }^{14}$. The corresponding band maximum of $\mathrm{Fe}(\mathrm{CN})_{5} \mathrm{CO}^{3-}$ appears at $305 \mathrm{~nm} \quad(\varepsilon=380)$. Although this band should be split into four components due to the reduction of symmetry to $\mathrm{C}_{4 \mathrm{v}}$ this splitting appears to be small. The other prominent absorption bands are assigned to CT (metal to ligand) transitions. $\mathrm{Fe}(\mathrm{CN})_{0}{ }^{4-}$ exhibits these absorption maxima at $218 \mathrm{~nm}$ and $200 \mathrm{~nm}^{14}$ and $\mathrm{Fe}(\mathrm{CN})_{5} \mathrm{CO}^{3-}$ at $227 \mathrm{~nm}$ and $208 \mathrm{~nm}$.

Our results show clearly that upon excitation aqueous $\mathrm{Fe}(\mathrm{CN})_{5} \mathrm{CO}^{3}$ - underwent a photoaquation under release of $\mathrm{CO}$ and formation of $\mathrm{Fe}(\mathrm{CN})_{5} \mathrm{H}_{2} \mathrm{O}^{3-}$. Within the limit of the experimental error the quantum yield was 0.9 .

Although the present study is restricted to the investigation of the LF photochemistry preliminary experiments showed that aqueous $\mathrm{Fe}(\mathrm{CN})_{5} \mathrm{CO}^{3-}$ released $\mathrm{CO}$ also upon CT excitation. At $250 \mathrm{~nm}$ irradiating wavelength the quantum yield of the reaction is considerably smaller $(\varnothing=0.5)$ than that obtained upon LF excitation at lower energies. It is possible that CT excitation is followed by an internal conversion to the lowest LF excited state

1 V. Balzani and V. Carassiti, "Photochemistry of Coordination Compounds", Academic Press, New York, N. Y. 1970, and references cited therein.

${ }^{2}$ S. Jimori, Z. Anorg. Allg. Chem. 167, 145 [1927].

3 W. Haberditzl, K.-D. Schleinitz, and H.-G. BARTEL, Z. Naturforsch. 23 b, 1397 [1968].

4a G. Emschwiller, C. R. Acad. Sci., Paris, 265C, 281 [1967].

tb G. Emschwiller, C. R. Acad. Sci., Paris 268 C, 692 [1969].

5 M. Shirom and G. Strein, J. Chem. Phys. 55, 3379 [1971].

B A. Lodzinska and R. Gogolin, Roczniki Chem. 47, 497 [1973].

7 G. Emschwiller, C. R. Acad. Sci., Paris, 270C, 1362 [1970].

8 Wyss, Sitzungsber. Soc. ind. Mülhausen [1899]; see also reference 9 .

- W. Manchot, E. Merry, and P. Woringer, Chem. Ber. 45, 2869 [1912].

10 P. Woringer, Dissertation Würzburg 1913. which initiates the release of CO. However, CT excitation may also lead to the production of photoelectrons as it occurs in the case of $\mathrm{Fe}(\mathrm{CN})_{6} \mathbf{t - 1}^{-15,16}$. Simultaneously, $\mathrm{Fe}(\mathrm{CN})_{5} \mathrm{CO}^{2-}$ should be formed as an intermediate. This $\mathrm{Fe}$ (III) complex is probably not stable and expected to release $\mathrm{CO} .{ }^{*} \mathrm{Fe}(\mathrm{CN})_{5} \mathrm{H}_{2} \mathrm{O}^{2-}$ may then recombine with the solvated electrons to yield $\mathrm{Fe}(\mathrm{CN})_{5} \mathrm{H}_{2} \mathrm{O}^{3}$ Hence the observation that $\mathrm{CO}$ was released upon CT excitation can not be used to discriminate between both mechanisms.

Finally, it should be mentioned that the photochemical dissociation of $\mathrm{Fe}(\mathrm{CN})_{5} \mathrm{CO}^{3-}$ and $\mathrm{Fe}(\mathrm{CN})_{6}{ }^{4-}$ resembles closely that of $\mathrm{CO}$ - and $\mathrm{CN}$-hemoglobin $^{18,19}$. We believe that this analogy is not accidental. On the basis of theoretical calculations it has been suggested that these hemoglobin compounds, which are also low-spin $\mathrm{Fe}$ (II) complexes, undergo the photochemical release of $\mathrm{CO}$ and $\mathrm{CN}^{-}$ from low lying LF excited states ${ }^{20}$.

* $\mathrm{Fe}(\mathrm{CN})_{5} \mathrm{CO}^{-8}$ is remarkably resistant to oxidadion ${ }^{10,11,17}$. This behaviour may be associated with the inability of $\mathrm{Fe}$ (III) to form carbonyl com. plexes $^{11}$.

Support for this research by the Deutsche Forschungsgemeinschaft and the Fond der Chemischen Industrie is gratefully acknowledged.

11 D. J. Kenney, T. P. Flynn, and J. B. Gallini, J. Inorg. Nucl. Chem. 20, 75 [1961].

12 C. G. Hatchard and C. A. Parker, Proc. Roy. Soc., Ser. A, 235, 518 [1956].

13 G. Ciuhandu and A. Chicu, Z. Anal. Chem. 263, 331 [1973], and references cited therein.

14 J. J. Alexander and H. B. Gray, J. Amer. Chem. Soc. 80, 4260 [1968].

15 W. L. Waltz and A. W. Adamson, J. Phys. Chem. 73,4250 [1969].

16 M. Shirom and G. Stein, J. Chem. Phys. 55, 3372 [1971].

17 W. Hieber, R. Nast, and C. Bartenstein, Z. Anorg. Allg. Chem. 272, 32 [1953].

18 C. Bonaventura, J. Bonaventura, E. Antonini, M. Brunori, and J. WYMan, Biochemistry 12, 3424 [1973], and references cited therein.

10 D. Kailin and E. F Hartree, Biochem. J. 61, 153 [1955].

20 M. Zerner, M. Gouterman, and H. Kobayashi, Theoret. Chim. Acta, 6, 363 [1966]. 